Original Article

\title{
IN VITRO EVALUATION OF ANTHELMINTIC ACTIVITY OF ETHANOLIC EXTRACT OF CENTELLA ASIATICA LINN. IN INDIAN ADULT EARTHWORMS
}

\author{
SWAGATA DATTA ${ }^{1}$, GEETANJALI NINGTHOUJAM ${ }^{1}$, CHRISTINA ZOSANGPUII ${ }^{1}$, PAONAM SHYAMASAKHI ${ }^{*}$, \\ NAMEIRAKPAM MEENA ${ }^{3}$
}

${ }^{1,2,3}$ Regional Institute of Medical Sciences, Department of Pharmacology, Imphal, Manipur, India, Pin 795004

Email: pharmarims19@gmail.com

Received: 04 May 2021, Revised and Accepted: 02 Jul 2021

\begin{abstract}
Objective: Helminthiasis is one of the most prevalent parasitic infestations worldwide posing a major threat to public health. The control of these nematodes has relied largely on the use of a limited number of anthelmintics. However, emerging resistance and side effects to the currently available anthelmintic drugs is a major concern and discovery of newer anthelmintics with a novel mode of action is the need of the hour. The present study is aimed to evaluate the anthelmintic activity of ethanolic extract of Centella asiatica Linn. (EECA) on Indian earthworms (Pheretima posthuma).
\end{abstract}

Methods: The earthworms were divided into 4 groups with 6 worms in each group. The anthelmintic activity of EECA at two different concentrations $(25 \mathrm{mg} / \mathrm{ml}$ and $50 \mathrm{mg} / \mathrm{ml})$ was evaluated by assessing the time of paralysis and time of death of the worms. Albendazole was used as standard and $2 \%$ gum acacia as control.

Results: Albendazole at $25 \mathrm{mg} / \mathrm{ml}$ showed the highest anthelmintic activity and had significant difference ( $<<0.001$ ) with EECA at both $25 \mathrm{mg} / \mathrm{ml}$ and $50 \mathrm{mg} / \mathrm{ml}$.

Conclusion: Both doses of the test drug showed anthelmintic activity but the extract at either dose was found to be less effective than the standard drug. Further studies with higher doses of the extract should be done to evaluate the anthelmintic activity in a dose-dependent manner.

Keywords: Helminthiasis, Centella asiatica Linn., Pheretima posthuma, Albendazole

(C) 2021 The Authors. Published by Innovare Academic Sciences Pvt Ltd. This is an open access article under the CC BY license (https://creativecommons.org/licenses/by/4.0/) DOI: https://dx.doi.org/10.22159/ijcpr.2021v13i5.1884 Journal homepage: https://innovareacademics.in/journals/index.php/ijcpr

\section{INTRODUCTION}

Helminthiasis also known as worm infestation is one of the most prevalent parasitic infestations both in developed and developing countries affecting around $1 / 3^{\text {rd }}$ of the world's population. As per WHO, around 1.5 billion people are infested with soil-transmitted helminths (STH) worldwide [1]. India has the highest burden of STH among all the countries contributing to one-fourth of total global cases which is prevalent among children of age group 1-14 y [2]. Overall prevalence of STH in India ranges from $13 \%$ to $66 \%$ [3]. Parasites causing infections can be broadly classified into tapeworms, flukes, and roundworms. Helminths cause infection by faeco-oral route or by direct entry through the skin of the host and then lodging in the intestine [4]. Intestinal worms cause decreased absorption, blood loss, intestinal or lymphatic obstruction and secretion of toxins which leads to health hazards like undernourishment, anaemia, eosinophilia and pneumonia [5]. In extreme cases of intestinal infestation, the mass and volume of the worms may cause tear of the muscular layer leading to peritonitis, volvulus and gangrene of the intestine [6].

A large number of anthelmintic drugs (AHDs) are now available in the market which include benzimidazole class like albendazole and mebendazole, macrocyclic lactones like ivermectin or pyrazinoisoquinoline derivative like praziquantel [7, 8]. The current anthelmintic therapies exert their action by incapacitating the parasite by causing damage and paralysis of the worm so that the immune system can eliminate it, or by altering its metabolic processes. But the metabolic requirements of these parasites vary greatly from one species to another and because of that drugs that are highly effective against one type of worm may be ineffective or less effective against others [9]. But the emergence of resistance to the currently available AHDs is a major concern and newer anthelmintics with a novel mode of action has become necessary [10].

Herbal drugs in recent years have become popular and also gained importance due to their safety, efficacy and cost effectiveness in treating various diseases. Centella asiatica Linn. known as 'Gotu Kola' in Hindi, 'Thanakuni' in Bengali, 'Peruk' in Manipuri, 'Indian Pennywort' in English is a medicinal plant that has been in use since prehistoric times in folk medicine for the treatment of a wide range of diseases. The herb is used for the treatment of wound healing, various skin conditions such as leprosy, varicose ulcers, eczema, psoriasis. It is also used in diarrhoea, liver diseases, fever, amenorrhoea, diseases of the female genitourinary tract. The plant also has analgesic, anticonvulsant, antidiabetic, antispasmodic, antiulcer, anxiolytic and nootropic actions [11-13]. Centella asiatica Linn. contains phytochemical constituents like tannins such as phlobatannins, saponins, flavonoids, terpenoids, alkaloids and cardiac glycosides etc [14].

As such, considering its use in gastro-intestinal ailments by locals, the present study was aimed at the evaluation of in vitro anthelmintic effect of ethanolic extract of leaves of Centella asiatica Linn. (EECA) on Indian earthworms (Pheretima posthuma).

\section{MATERIALS AND METHODS}

\section{Collection of plant materials}

The present study was conducted in the Department of Pharmacology, Regional Institute of Medical Sciences, Imphal, Manipur. The plant Centella asiatica Linn. was collected from Lamphel local market, Imphal, Manipur and was authenticated by the Department of Botany, D. M. College, Imphal having Acc. No. DMH 09.15.

\section{Preparation of plant extract}

The leaves of the plant Centella asiatica Linn. were shade dried and powdered using a mixer grinder. Powdered dry plant material (50 gm) was extracted with $100 \mathrm{ml}$ ethanol for $24 \mathrm{~h}$ and thus ethanolic extract was obtained using soxhlet apparatus manufactured by Jain Scientific Glass Works, Ambala Cantt, Haryana, India. The extract was filtered and concentrated under vacuum-sounding apparatus for $30 \mathrm{~min}$ and then stored at $4{ }^{\circ} \mathrm{C}$ [15]. The percentage yield was 21 $\%$ and the extract thus obtained was used for the anthelmintic study. 


\section{Worm collection and authentication}

The study was done on adult Indian earthworm Pheretima posthuma because of its similar anatomical and physiological features to Ascaris lumbricoides $[16,17]$. The earthworms $(5-8 \mathrm{~cm}$ in length) were collected from moist soil and authenticated by the Department of Life Sciences, Manipur University. They were cleaned with normal saline (NS $0.9 \%$ ) to remove soil and faecal matter.

\section{Phytochemical analysis}

The preliminary phytochemical analysis of the plant extract was carried out using a standard procedure to identify various constituents [18].

\section{Experimental design}

The earthworms were divided into 4 groups with six worms in each group. Standard and test drugs were dissolved in $2 \%$ gum acacia and $10 \mathrm{ml}$ of the desired formulation were poured in separate petri dishes and were kept under room temperature. The earthworms were placed in the petri dishes containing the extract solutions or the standard drug as mentioned below in table 1 .

Table 1: Allotment of earthworms in different groups and their treatment

\begin{tabular}{ll}
\hline Group & Treatment \\
\hline 1 (Control) & $2 \%$ gum acacia \\
2 (Standard) & Albendazole suspension at a dose of $25 \mathrm{mg} / \mathrm{ml}$ \\
3 (Test $A)$ & EECA at a dose of $25 \mathrm{mg} / \mathrm{ml}$ \\
4 (Test B) & EECA at a dose of $50 \mathrm{mg} / \mathrm{ml}$ \\
\hline
\end{tabular}

\section{Evaluation of anthelmintic activity}

The living or viable worms were kept under close observation. External stimuli was frequently applied to each worm which stimulated and induced movement in live earthworms. Time taken for paralysis of the worms were noted when no spontaneous movement could be observed except when shaken vigorously. Time taken for death of worms were recorded when worms did not move even after vigorous shaking or when dipped in warm water $\left(50^{\circ} \mathrm{C}\right)$ which was followed by gradual fading of their body color [19].

\section{Statistical analysis}

Data obtained was analysed using One way ANOVA followed by Bonferroni test post hoc. Results were expressed in mean \pm SEM.

\section{RESULTS}

The ethanolic extract of leaves of Centella asiatica Linn. (EECA) had significant anthelmintic activity when compared with control $(\mathrm{p}<0.001)$. The standard drug albendazole at $25 \mathrm{mg} / \mathrm{ml}$ showed the best activity for time of paralysis and death $(22.89 \pm 3.21$ and $28.44 \pm 3.22 \mathrm{~min}$ respectively), while EECA $(25 \mathrm{mg} / \mathrm{ml})$ showed $56.21 \pm 3.29$ and $61.75 \pm 3.61 \mathrm{~min}$ respectively and EECA $(50 \mathrm{mg} / \mathrm{ml})$ showed $38.55 \pm 2.66$ and $44.41 \pm 3.76$ min respectively for time of paralysis and death (table 2). Moreover, higher dose of EECA (50 $\mathrm{mg} / \mathrm{ml})$ showed significant $(\mathrm{p}<0.001)$ increased anthelmintic activity as depicted by the reduced time of paralysis and death (fig. 1). However, the extract at either dose was found to be less effective than the standard drug.

Table 2: In vitro anthelmintic activity of EECA on Indian earthworms

\begin{tabular}{llcc}
\hline Group & Drugs & Time of paralysis (in minutes) & Time of death (in minutes) \\
\hline 1 & Control (2\% gum acacia) & - & - \\
2 & Standard (Albendazole 25 mg/ml) & $22.89 \pm 3.21 \#$ & $28.44 \pm 3.22 \#$ \\
3 & Test A (EECA 25 mg/ml) & $56.21 \pm 3.29^{*}$ & $61.75 \pm 3.61 *$ \\
4 & Test B (EECA 50 mg/ml) & $38.55 \pm 2.66^{*} \#$ & $44.41 \pm 3.76^{*} \#$ \\
\hline
\end{tabular}

$\mathrm{n}=6$ in each group, values are mean \pm SEM. Symbols*, \#were used to compare with groups 2 and 3 respectively. p<0.001

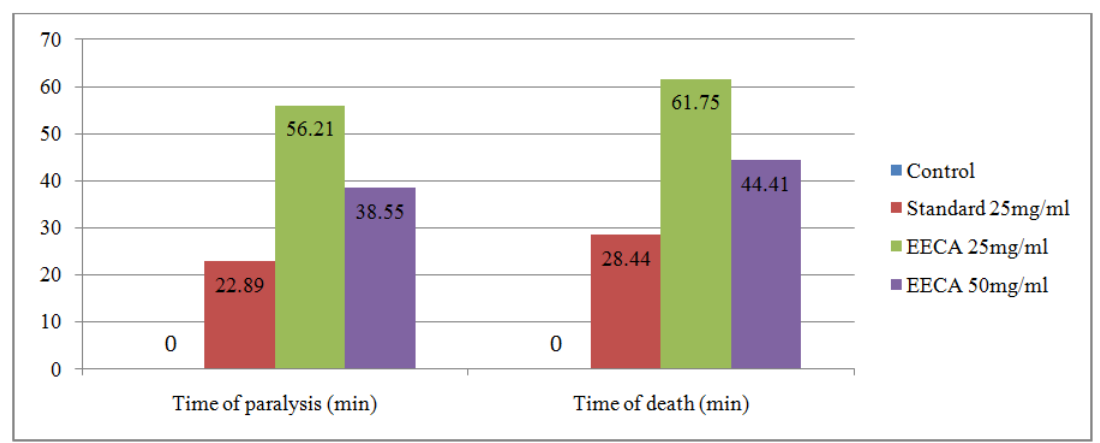

Fig. 1: Anthelmintic activity of EECA when compared to standard drug albendazole on time of paralysis and time of death

\section{DISCUSSION}

The emergence of resistance and toxicity to the conventional anthelmintic drugs and the increasing concern over the presence of drug residues in animal products has led to a renewal of interest in the use of plant-based drugs. Evaluation of anthelmintic activity of new plant compounds by in vitro methods using free living stages of parasitic nematodes have become popular [20]. Because of their low-cost effectiveness, simplicity and rapid turnover in vitro techniques are preferred over in vivo methods [21].

The preliminary phytochemical analysis shows presence of polyphenolic compound tannins. Tannins present in the extract possibly can interfere with energy generation in helminths by uncoupling oxidative phosphorylation which is similar to some synthetic phenolic anthelmintics e. g niclosamide, oxyclozanide, bithionol etc. Tannins can also exert anthelmintic action by binding to free proteins in the GIT of host or glycoprotein on the cuticle of the parasite and causes death [22]. Phytochemical investigation of the extract also reveals presence of saponin which has membrane permeabilizing and pore forming property. This is similar to two conventional anthelmintic drugs such as praziquantel and toltrazuril. Thus, permeability of the cell membrane of the parasites is affected which forms vacuoles, resulting in disintegration of monogenea teguments [23]. Presence of alkaloids can block intake of acetylcholine from the host which expels out the worms by peristaltic movement of intestine [24].

Conventional anthelmintic drugs like albendazole, piperazine citrate and mebendazole are being used in these studies. Albendazole is a safe, highly effective therapy for parasitic infections and an established standard drug in anthelmintic studies. Possible 
mechanism of action is thought to be inhibition of microtubule polymerization by binding to $\beta$-tubulin. The selective toxicity of this agent against helminths results from higher affinity for parasite $\beta$ tubulin than for the same target in higher eukaryotes [7]. The least time taken for paralysis and death of worms by albendazole correlates with previous studies [19].

Time taken for paralysis and death of the worms by EECA can correspond with observations of the previous anthelmintic studies on the plant extracts [25]. The extract is more effective at $50 \mathrm{mg} / \mathrm{ml}$ but the extract at either dose was found to be less effective than the standard drug.

\section{CONCLUSION}

The discovery of a potent remedy from plant origin will be a great advancement in the treatment of helminthic infections. Use of these plants in folk medicine suggests that they represent an economic and safe alternative to treat infectious diseases. The current study evidenced that the ethanolic extracts of Centella asiatica has a promising in vitro anthelmintic activity. However further studies with higher doses of the plant are required to evaluate the dose dependent anthelmintic activity and also to determine the active principle responsible for exact mechanism of anthelmintic activity.

\section{ACKNOWLEDGMENT}

The authors wish to thank Department of Botany, D. M. College, Imphal for authenticating the plant and Department of Life Sciences, Manipur University for authenticating the earthworms. The authors are also grateful to the laboratory technicians for assisting throughout the work.

\section{FUNDING}

Nil

\section{AUTHORS CONTRIBUTIONS}

All the authors have contributed equally.

\section{CONFLICT OF INTERESTS}

Declared none

\section{REFERENCES}

1. Soil-transmitted helminth infections. World Health Organisation. Available from: https://www.who.int/ Newsroom/Factsheets/Detail. [Last accessed on 31 Mar 2021]

2. Eliminating soil-transmitted helminthiases as a public health problem in children. World Health Organisation. Available from: https://www.who.int/neglected_diseases/resources. [Last accessed on 31 Mar 2021]

3. Dhaka R, Verma R, Kumar R, Chayal V, Bhalla K, Singh R, et al. Pattern and determinants of soil-transmitted helminthiasis in a rural area of Haryana: a school-based study. J Family Med Prim Care 2019;8:1971-5.

4. Chatterjee KD. Parasitology. 13th ed. New Delhi: CBS Publishers and Distributors Pvt. Ltd; 2015.
5. Bundy DA. Immunoepidemiology of intestinal helminthic infection I: The global burden of intestinal nematode disease. Trans Royal Soc Trop Med Hyg 1994;8:259-61.

6. E Madiba T, P Hadley G.Surgical management of worm volvulus. S Afr J Surg 1996;34:33-6.

7. Tripathi KD. Essentials of medical pharmacology. 8th ed. New Delhi: Jaypee Brother Medical Publishers (P) Ltd; 2019.

8. Keiser J, McCarthy J, Hotez P. Chemotherapy of helminth infections. In: Brunton LL, Hilal-dandan R, Knollmann BC. editors. Goodman and Gilman's the pharmacological basis of therapeutics. 13th ed. New York: McGraw Hill Education; 2018. p. 1001-10.

9. Udavant $\mathrm{PB}$, Satyanarayana SV, Upasani CD. In vitro anthelmintic activity of stems of Cuscuta reflexa. Int J Bioassays 2012;1:18-9.

10. Yadav P, Singh R. A review on anthelmintic drugs and their future scope. Int J Pharm Pharm Sci 2011;3:17-21.

11. Saranya S, Nair AV, Prathapan MP, Neethu AS, Kumar NS. Phytochemical analysis of Centella asiatica L. leaf extracts. Int J Adv Res 2017;5:1828-32.

12. Gohil KJ, Patel AJ, Gajjar AK. Pharmacological review on Centella asiatica: a potential herbal cure-all. Indian J Pharm Sci 2010;72:546-56.

13. Antony B, Santhakumari G, Merina B, Sheeba V, Mukkadan J. Hepatoprotective effect of Centella asiatica (L) in carbon tetrachloride-induced liver injury in rats. Indian J Pharm Sci 2006;68:772-6.

14. Krishnaiah D, Devi T, Bono A, Sarbatly R. Studies on phytochemical constituents of six Malaysian medicinal plants. J Med Plant Res 2009;3:67-72.

15. Knevel AM, Digangi FE. Jenkins' quantitative pharmaceutical chemistry. 7th ed. New York: McGraw Hill Book Co; 1977.

16. Vidyarthi RD. A textbook of zoology. 14th ed. New Delhi: S Chand and Co; 1977.

17. Vigar Z. Atlas of medical parasitology. 2nd ed. Singapore: PG Publishing House; 1984.

18. Kokate CK. Practical pharmacognosy. New Delhi: Vallabh Prakashan; 1985.

19. Sinha SK, Mayanglambam M, Nongthombam S, Momin RG, Muralidas A, Paonam S. In vitro evaluation of anthelmintic activity of ethanolic extract of leaves of Toona ciliata M. Roem on Indian earthworm. Int J Adv Res 2019;7:250-3.

20. A Asase, AA Oteng Yeboah, GT Odamtten, MSJ Simmonds. Ethnobotanical study of some ghanaian antimalarial plants. J Ethnopharmacol 2005;99:1221-9.

21. S Markus, M Ernst. Medicinal plants in tropical countries: georg thieme verlag, Rudigerstrasse, Germany; 2005.

22. Kaur S, Kumar B, Puri S, Tiwari P, Divakar K. Comparative study of anthelmintic activity of aqueous and ethanolic extract of bark of Holoptelea integrifolia. Int J Drug Dev Res 2010;2:758-63.

23. Patel J, Kumar GS, Qureshi MS, Jena PK. Anthelmintic activity of ethanolic extract of whole plant of Eupatorium odoratum. Int Phytomed 2010;2:127-32.

24. Wang GX, Han J, Zhao LW, Jiang DX, Liu YT, Liu XL. Anthelmintic activity of steroidal saponins from paris polyphylla. Phytomedicine 2010;17:1102-5

25. Shekhawat N, Vijayvergia R. To study of anthelmintic activity of extracts of some medicinal plants. Int J Computat Sci Math 2011;3:183-7. 